\title{
REE Characteristics and REE Mixing Modeling of the Proterozoic Quartzites and Sandstones
}

\author{
H. Wani \\ Department of Geology, Amar Singh College, Srinagar, India \\ Email: wani79@gmail.com
}

How to cite this paper: Wani, H. (2017) REE Characteristics and REE Mixing Modeling of the Proterozoic Quartzites and Sandstones. International Journal of Geosciences, 8, 16-29.

http://dx.doi.org/10.4236/ijg.2017.81002

Received: November 14, 2016

Accepted: January 19, 2017

Published: January 22, 2017

Copyright $\odot 2017$ by author and Scientific Research Publishing Inc. This work is licensed under the Creative Commons Attribution International License (CC BY 4.0).

http://creativecommons.org/licenses/by/4.0/

\begin{abstract}
Rare earth elements (REE) in sedimentary rocks are most suitable for source rock characterization. Rare earth element data of the sandstones of the unmetamorphosed Meso-Neoproterozoic Chhattisgarh and Indravati basins and the metamorphosed Paleoproterozoic Sakoli and Saucer basins of the Bastar craton have been studied for source rock characterization. The quartzites have higher $\Sigma R E E$ mean value (145 ppm) compared to the sandstones (34 ppm). The REE patterns of all the three formations of the Chandarpur Group of the Chhattisgarh basin and the Tiratgarh Formation of the Indravati basin are uniform and there are no systematic differences in REE patterns among different formations of the Chandarpur Group and the Tiratgarh Formation. The REE patterns of the quartzites are similar to the REE patterns of the sandstones. Chondrite-normalized REE patterns with LREE enrichment and a strong negative $\mathrm{Eu}$ anomaly of the sandstones and quartzites gives a broad hint about felsic source rocks. The source rocks are identified as Archean granite and gneiss of the Bastar craton. The REE mixing modeling of the sandstones and quartzites suggest that the exposed the Proterozoic upper crust of the Bastar craton during the sedimentation of the Paleoproterozoic Sakoli and saucerand the Meso-Neoproterozoic Chhattisgarh and Indravati basins of the Bastar craton was largely consisted of gneissic rocks (70\%), with a little contribution (20\%) from Late Archean $(2.5 \mathrm{Ga})$ granites. The present study does not suggest any significant change in the upper crustal composition during Proterozoic in the Bastar craton.
\end{abstract}

\section{Keywords}

Rare Earth Elements, Sandstones, Quartzites, Source Rock, Proterozoic Crustal Composition

\section{Introduction}

Sedimentary rocks preserve a record of the provenance [1] which in turn is 
important to understand the geologic history, tectonic setting and crustal evolution during the deposition of sediments. It is, however, true that framework grains, on its own, sometimes fail to reflect the true crustal setting, because the sediment particles get modified during diagenesis and weathering. Hence, judicious chemical analyses of sedimentary rocks provide important information about the characteristics of the provenance. Several trace elements like $\mathrm{Y}, \mathrm{Th}, \mathrm{Zr}$, $\mathrm{Hf}, \mathrm{Nb}, \mathrm{Sc}$ and rare earth elements (REE) are most suitable for discriminations of provenance and tectonic setting because of their relatively low mobility during sedimentary processes and their short residence times in seawater [2]. These elements probably are transferred quantitatively into clastic sediments during weathering and transportation, reflecting the signature of the parent materials and hence are expected to be more useful in discriminating tectonic environments and source rock compositions [1] [3] [4]. Rare earth elements (REEs) have very similar geochemical properties and are not easily fractionated during sedimentary processes and will not be affected to any great extent during a silicification episode [1]. The REEs are considered to be essentially uniform in abundances in fine grained clastic sedimentary rocks and are not significantly affected by weathering, diagenesis and most forms of metamorphism [5] [6] [7]. The REEs are, therefore, very important in understanding crustal evolution.

In this paper, we have used the rare earth element (REE) data of the sandstones of the unmetamorphosed Meso-Neoproterozoic Chhattisgarh and Indravati basins and the metamorphosed Paleoproterozoic Sakoli and Saucer basins of the Bastar craton for source rock characterization and to know the Proterozoic crustal composition.

\section{Geological Setting}

Extensive Meso-Neoproterozoic sedimentary successions occur in a number of cratonic basins in the IndianPeninsula. The basins occupy large areas of cratonic blocks [8]. The Bastar craton is bounded at the periphery by the Proterozoic mobile belts viz. Mahanadi graben in the northeast, Godavari graben in the southwest, Satpura mobile belt in the north-northwest and Eastern Ghat mobile belt in the southwest (Figure 1). The Proterozoic sedimentary basins of the Bastar craton have been divided into the Paleoproterozoic and the Meso-Neoproterozoic sedimentary basins [11]. The Paleoproterozoic Sakoli and Sausar basins of the Bastar craton occur in the northern part of the Bastar craton in the proximity of Central Indian Tectonic Zone (CITZ). These basins are highly deformed and metamorphosed [11]. The Sakoli and Sausar sediments show greenschist to lower amphibolite facies of metamorphism [12]. The Sakoli Group consists of sedimentary rocks including mostly metapelite and quartzite with basalt and rhyolite (Table 1). The Sausar Group comprises of quartzite, pelite and carbonate associations along with stratiform manganese deposits [15] (Table 1). The age of the sedimentation of the Sakoli and Sausar basins have been considered to be Paleoproterozoic [16] [17] [18]. The Meso-Neoproterozoic sediments of the Bastar craton occur in two major basins viz. the Chattisgarh and Indravati basins (Figure 1). 
The rocks of these basins are unmetamorphosed conglometrate, sandstone, limestone, chert and dolomite (Table 1). The age of the Chattisgarh and Indravati basins have been placed in the Meso-Neoproterozoic era [19].

\section{Sampling and Methodology}

The fresh samples of the Paleoproterozoic quartzites and the Meso-Neoproterozoic

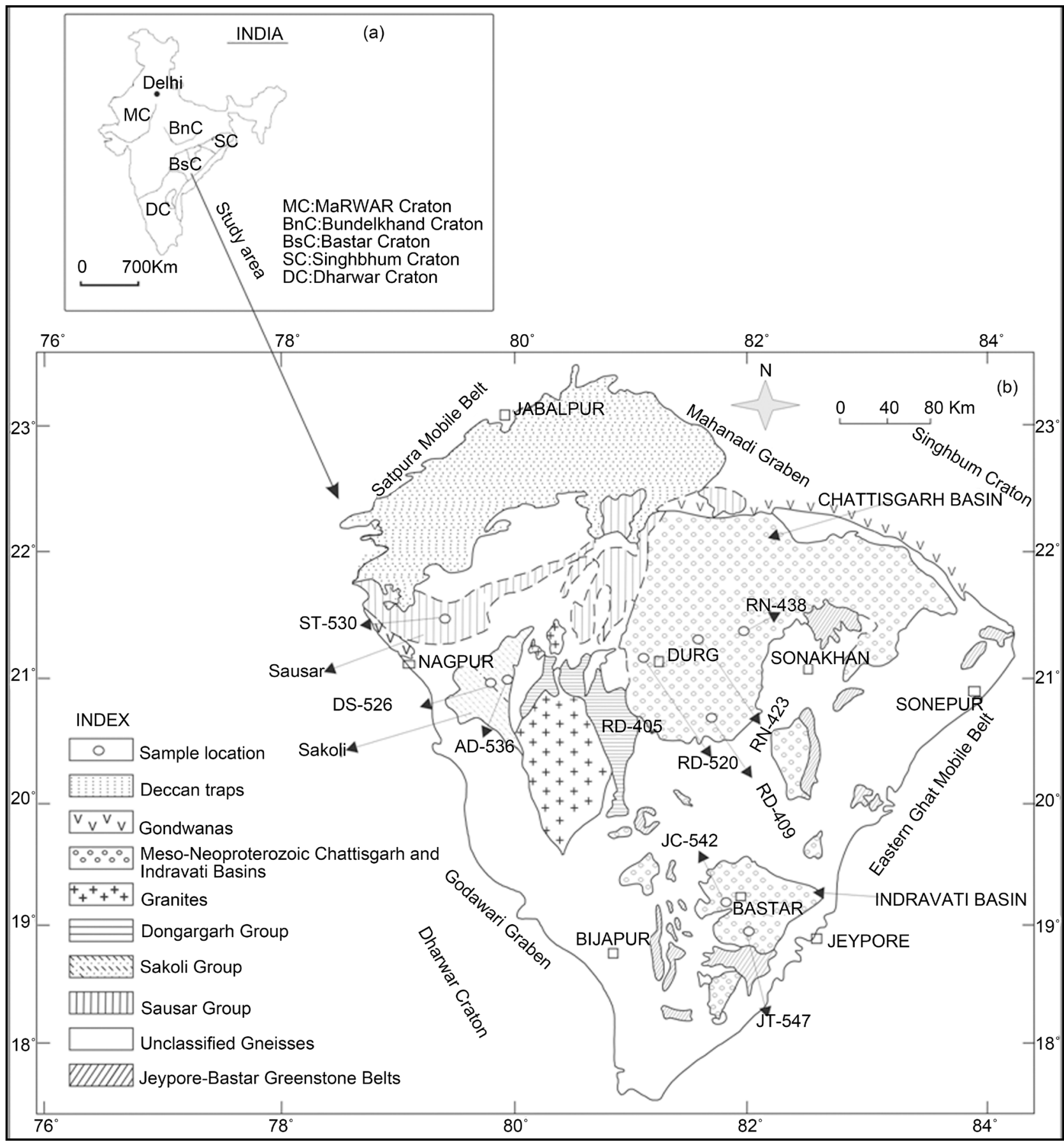

Figure 1. (a) Geological map of the India showing major Archean cratons including the Bastar craton [9]. (b) Geological map showing locations of the Paleoproterozoic and Meso-Neoproterozoic basins of the Bastar craton from which the samples have been taken [10]. Numbers refer to sample locations. 
Table 1. The general stratigraphic successions of the Proterozoic sedimentary basins of the Bastar craton are given below [11] [13] [14].

\begin{tabular}{|c|c|c|c|}
\hline \multicolumn{4}{|c|}{ Meso-Neoproterozoic basins of the Bastar craton } \\
\hline \multirow[t]{2}{*}{ Indravati basin } & & \multicolumn{2}{|c|}{ Chattisgarh basin } \\
\hline & & \multicolumn{2}{|c|}{ (Chattisgarh Supergroup) } \\
\hline \multirow[t]{9}{*}{ Indravati Group } & & \multicolumn{2}{|c|}{ Raipur Group } \\
\hline & & Formation & Lithology \\
\hline & & $\begin{array}{l}\text { Tarenga } \\
\text { Formation }\end{array}$ & $\begin{array}{l}\text { Purple shale, and } \\
\text { purplelimestone }\end{array}$ \\
\hline & & Chandi & Grey and pink \\
\hline & & Formation & limestone \\
\hline & & Gunderdehi & Pink and purple \\
\hline & & Formation & shale/grey shale \\
\hline & & Charmuria & Grey limestone/ \\
\hline & & Formation & White to buff clays \\
\hline Formation & Lithology & \multicolumn{2}{|c|}{ Chandrapur Group } \\
\hline $\begin{array}{l}\text { Jagdalpur } \\
\text { Formation }\end{array}$ & $\begin{array}{l}\text { Calcareous Shales with purple and gray } \\
\text { stromatolitic dolomite }\end{array}$ & $\begin{array}{l}\text { Kansapathar } \\
\text { Formation }\end{array}$ & White sandstone \\
\hline $\begin{array}{l}\text { Kanger } \\
\text { Limestone }\end{array}$ & Purple limestone grey limestone & $\begin{array}{l}\text { Chopardih } \\
\text { Formation }\end{array}$ & $\begin{array}{l}\text { Reddish brown and } \\
\text { olive green sandstone }\end{array}$ \\
\hline Cherakur & Purple shale with arkosic sandstone and & Lohardih & White pebbly \\
\hline \multirow[t]{2}{*}{$\begin{array}{l}\text { Tiratgarh } \\
\text { Formation }\end{array}$} & $\begin{array}{l}\text { Chitrakot sandstone member } \\
\text { (quartz arenite) }\end{array}$ & & \\
\hline & $\begin{array}{l}\text { Mendri sandstone member } \\
\text { (subarkose and conglomerate) }\end{array}$ & & \\
\hline & Unconformity & & \\
\hline
\end{tabular}

sandstones were collected from the outcrops. Locations of the samples are shown in Figure 1. The rock samples have been collected from the Paleoproterozoic Sakoli and Sausar basins and the Meso-Neoproterozoic Chhattisgarh and Indravati basins of the Bastar craton with a view to observe spatial as well as stratigraphic variations (Table 1). Extensive care has been taken to collect only the fresh samples from the outcrops. Prior to geochemical analysis, the rocks were studied under the microscope. Effects of alterations were observed in thin sections, and the samples which show no alteration effects, were opted for the geochemical studies. After careful petrographic studies from the point of view of secondary alterations, and also for representation of maximum possible spatial and temporal variations of the clastic rocks, altogether ten samples were selected for the geochemical analysis. Out of the ten samples, three quartzite samples belong to the Pawni Formation of the Sakoli basin, and the Junewani Formation of the Sausar basin. Five sandstone samples belong to the Lohardih Formation, the Chopardih Formation and the Kansapathar Formation of the Chhattisgarh basin, 
and two sandstone samples belong to the Tiratgarh Formation of the Indravati basin. Trace elements and rare earth elements were analyzed on ICP-MS (Perkin Elmer Sciex ELAN DRC II) at National Geophysical Research Institute (NGRI), Hyderabad. The precision of ICP-MS trace elements and REE data is better than 5\%. International standards like GSR-4 (sandstone) and JG-2 (quartzite) were used for calibration and testing of accuracy. Details of the analytical techniques, accuracy and precision of the instrument are described in Roy et al. [20]. The rare earth data of the sandstones and quartzites are presented in Table 2.

\section{Results}

Total REE concentration in the sandstones of the Chandarpur Group is variable with the highest value in the Chopardih Formation (39 ppm) and the lowest value in the Kansapathar Formation (13 ppm). However, the $\Sigma$ REE concentration

Table 2. Rare earth element (REE) and trace element data of the sandstones and quartzites.

\begin{tabular}{|c|c|c|c|c|c|c|c|c|c|c|c|c|}
\hline \multirow{4}{*}{$\begin{array}{l}\text { Elements } \\
\text { (in ppm) }\end{array}$} & \multirow{4}{*}{$\begin{array}{c}\text { LF } \\
\text { RN-438 }\end{array}$} & \multicolumn{6}{|c|}{ Sandstones } & \multicolumn{5}{|c|}{ Quartzites } \\
\hline & & \multicolumn{3}{|c|}{ Chhattisgarh basin } & \multirow{2}{*}{\multicolumn{3}{|c|}{$\begin{array}{c}\text { Indravati basin } \\
\text { TF }\end{array}$}} & \multirow{2}{*}{\multicolumn{3}{|c|}{$\begin{array}{c}\text { Sakoli basin } \\
\text { PF }\end{array}$}} & \multirow{2}{*}{\multicolumn{2}{|c|}{$\begin{array}{c}\text { Saucer basin } \\
\text { JF }\end{array}$}} \\
\hline & & $\mathrm{CF}$ & & KF & & & & & & & & \\
\hline & & $\mathrm{RN}-423$ & $\mathrm{RD}-405$ & RD-409 & $\mathrm{RD}-520$ & JC-542 & JT-547 & Average & DS-526 & $\mathrm{AD}-536$ & ST-530 & Average \\
\hline $\mathrm{La}$ & 8.6 & 9.4 & 3.4 & 2.9 & 4 & 16.9 & 9.2 & 7.8 & 5.4 & 69.7 & 21.3 & 32.2 \\
\hline $\mathrm{Ce}$ & 16.9 & 17.8 & 6.2 & 5.3 & 7 & 30.7 & 18 & 14.6 & 11.7 & 136.5 & 39 & 62.4 \\
\hline $\operatorname{Pr}$ & 1.7 & 1.7 & 0.75 & 0.62 & 0.77 & 3.4 & 2 & 1.6 & 1 & 14.5 & 3.9 & 6.48 \\
\hline $\mathrm{Nd}$ & 6.7 & 6.6 & 2.7 & 2.2 & 2.2 & 12.2 & 8 & 5.8 & 3.7 & 57 & 13.9 & 24.9 \\
\hline $\mathrm{Sm}$ & 1 & 0.98 & 0.56 & 0.47 & 0.33 & 2.2 & 1.6 & 1 & 0.74 & 10.8 & 2.5 & 4.7 \\
\hline $\mathrm{Eu}$ & 0.22 & 0.16 & 0.13 & 0.11 & 0.07 & 0.43 & 0.29 & 0.2 & 0.1 & 1.6 & 0.28 & 0.67 \\
\hline Gd & 0.83 & 0.84 & 0.46 & 0.37 & 0.39 & 2 & 1.3 & 0.91 & 0.62 & 8.8 & 1.7 & 3.7 \\
\hline $\mathrm{Tb}$ & 0.12 & 0.11 & 0.08 & 0.06 & 0.07 & 0.43 & 0.22 & 0.16 & 0.1 & 1.4 & 0.26 & 0.61 \\
\hline Dy & 0.56 & 0.58 & 0.39 & 0.31 & 0.38 & 2.7 & 1 & 0.87 & 0.66 & 10.3 & 1.5 & 4.1 \\
\hline Ho & 0.1 & 0.09 & 0.07 & 0.05 & 0.08 & 0.57 & 0.22 & 0.17 & 0.07 & 1.2 & 0.16 & 0.48 \\
\hline $\mathrm{Er}$ & 0.28 & 0.3 & 0.23 & 0.16 & 0.24 & 1.7 & 0.62 & 0.5 & 0.23 & 4.2 & 0.53 & 1.6 \\
\hline $\mathrm{Tm}$ & 0.04 & 0.05 & 0.04 & 0.03 & 0.04 & 0.32 & 0.11 & 0.09 & 0.03 & 0.57 & 0.08 & 0.23 \\
\hline $\mathrm{Yb}$ & 0.33 & 0.32 & 0.28 & 0.19 & 0.26 & 1.9 & 0.65 & 0.57 & 0.36 & 6 & 0.87 & 2.4 \\
\hline $\mathrm{Lu}$ & 0.04 & 0.04 & 0.03 & 0.02 & 0.04 & 0.32 & 0.1 & 0.09 & 0.06 & 1 & 0.16 & 0.41 \\
\hline $\mathrm{Zr}$ & 65.2 & 76.3 & 72.8 & 71.9 & 57.3 & 1243.2 & 154.7 & ND & 80.7 & 648.8 & 118.4 & ND \\
\hline $\mathrm{Th}$ & 1.9 & 2 & 1.9 & 1.5 & 1 & 9.3 & 4.3 & ND & 4.7 & 19.1 & 15.3 & ND \\
\hline $\mathrm{Y}$ & 2.9 & 2.6 & 2.2 & 1.7 & 2.4 & 16.4 & 6 & ND & 3.7 & 65.5 & 8.8 & ND \\
\hline LREE & 34.9 & 36.48 & 13.61 & 11.49 & 14.3 & 65.4 & 38.8 & 30.8 & 22.54 & 288.5 & 80.6 & 130 \\
\hline HREE & 2.52 & 2.49 & 1.71 & 1.3 & 1.57 & 10.37 & 4.51 & 3.56 & 2.23 & 35.07 & 5.54 & 14.2 \\
\hline LREE/HREE & 13.8 & 14.6 & 7.9 & 8.8 & 9.1 & 6.3 & 8.6 & 8.6 & 10.11 & 8.2 & 14.5 & 9.2 \\
\hline$\sum \mathrm{REE}$ & 37.42 & 39 & 15.32 & 13 & 15.87 & 76 & 43.31 & 34 & 24.77 & 323.6 & 86.14 & 145 \\
\hline$(\mathrm{La} / \mathrm{Yb}) \mathrm{n}$ & 18.6 & 21 & 8.7 & 10.9 & 11 & 6.3 & 10.1 & 9.8 & 10.7 & 8.3 & 17.5 & 9.6 \\
\hline$(\mathrm{Gd} / \mathrm{Yb}) \mathrm{n}$ & 2 & 2.1 & 1.3 & 1.6 & 1.2 & 0.8 & 1.6 & 1.3 & 1.4 & 1.2 & 1.6 & 1.2 \\
\hline $\mathrm{Eu} / \mathrm{Eu}^{*}$ & 0.73 & 0.53 & 0.78 & 0.8 & 0.59 & 0.62 & 0.6 & 0.63 & 0.45 & 0.5 & 0.4 & 0.49 \\
\hline
\end{tabular}

LF-Lohardih Formation; CF-Chopardih Formation; KF-Kansapathar Formation; TF-Tiratgarh Formation; PF-Pawni Formation; JF-Junewani Formation; ND-not determined. 
of the Tiratgarh Formation of the Indravati Group is higher than all the three formations of the Chandarpur Group (76 ppm). The chondrite normalized REE patterns [21] of all the three formations of the Chandarpur Group of the Chhattisgarh basin and the Tiratgarh Formation of the Indravati basin are uniform and there are no systematic differences in REE patterns among different formations of the Chandarpur Group and the Tiratgarh Formation (Figure 2). The REE patterns of the quartzites are similar to the REE patterns of the sandstones (Figure 2).

When the mean REE concentration of the Paleoproterozoic quartzites are compared with the Meso-Neoproterozoic sandstones, it is observed that the quartzites have higher REE mean value (145 ppm) than the sandstones (34 ppm). However, on an average, the sandstones and the quartzites have REE abundances lower than that of the NASC due to higher quartz content.

The REE contents show large variations between the quartzites and the sandstones. It may be due to the reason that REEs normally reside in fine fraction and it has been inferred that trivalent REEs are readily accommodated in most of the clay-mica minerals (phyllosilicates) enriched with alumina and ferric iron [22] [23]. Thus, the sandstones with higher quartz and lower mica content have lower REE content, while the quartzites with lower quartz and higher mica content have higher content of REE than the sandstones [5]. Good positive correlation of LREE and HREE with $\mathrm{Zr}$, Th and $\mathrm{Y}$ of the sandstones indicate allanite, monazite and zircon control on REE (Figure 3). In contrast, LREE and HREE in the quartzites do not show good correlation with $\mathrm{Zr}$, Th and $\mathrm{Y}$ indicating little or no control of allanite, monazite and zircon on REE in the quartzites (Figure 3).

\section{Discussion}

\subsection{Source Rock Characterization}

Although there are variations in absolute concentrations of REE between sandstones formations of the Chandarpur group and the Tiratgarh Formation of



Figure 2. Chondrite-normailzed REE patterns for the sandstones of the Meso-Neoproterozoic Chattisgarh and Indravati basins and, the quartzites of the Paleoproterozoic Sakoli and Sausar basins of the Bastar craton. 


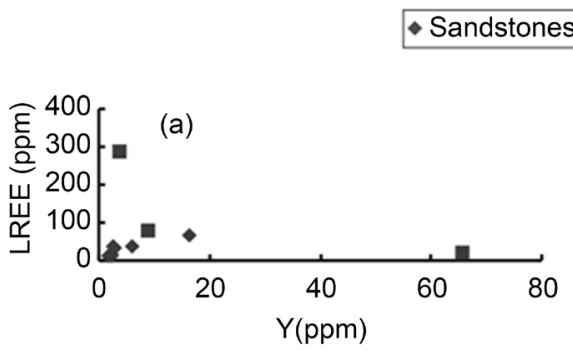

Quartzites
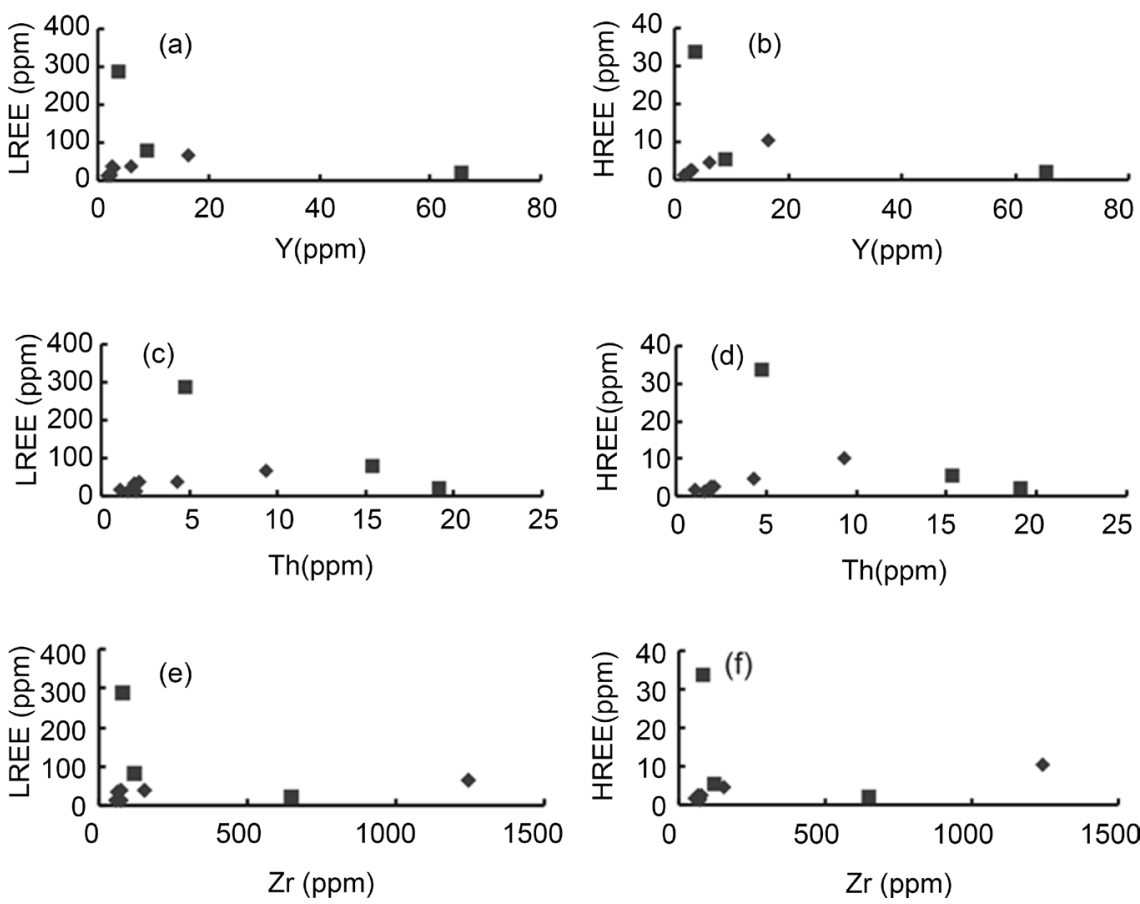

Figure 3. Plots of REE vs. Y, Th and Zr for the sandstones of the Meso-Neoproterozoic Chhattisgarh and Indravati basins and, the quartzites of the Paleoproterozoic Sakoli and Sausar basins of the Bastar craton.

the Indravati Group, but they have almost similar ratios of LREE/HREE (avg. 8.6). The REE patterns of the sandstones are highly fractionated and uniform with LREE enrichment $(\mathrm{La} / \mathrm{Yb}) \mathrm{n}=9.8$, flat $\operatorname{HREE}(\mathrm{Gd} / \mathrm{Yb}) \mathrm{n}=1.3$ and significant Eu anomaly (avg. 0.63) (Table 2). There are no systematic variations in REE patterns among the sandstones formations (Figure 2).

The quartzites also show variations in absolute concentrations of REE. The quartzites have almost similar ratios of LREE/HREE (avg. 9.2), $(\mathrm{Gd} / \mathrm{Yb}) \mathrm{n}=1.2$ and $\mathrm{Eu} / \mathrm{Eu}^{*}=0.49$ to sandstones (Table 2). The REE patterns of the quartzites are highly fractionated and there are no systematic variations in REE patterns among the quartzites samples (Figure 2). When compared to NASC, the sandstones and the quartzites have lower $\Sigma$ REE abundances. It is due to higher quartz concentration and lower amount of heavy minerals which is consistent with petrography. However, when quartzites are compared with sandstones, it is observed that quartzites have higher $\Sigma \mathrm{REE}$ abundances (Table 2). Understanding the origin of the depletion of Eu, relative to other chondrite normalized REE in clastic sedimentary rock is fundamental to any interpretation of crustal composition and evolution [2]. The most significant observation in this regard is that virtually all post-Archean sedimentary rocks are characterized by Eu depletion of approximately of comparable magnitude. The most striking evolutionary pattern of sedimentary trace element patterns is for $\mathrm{Eu} / \mathrm{Eu}^{*}$. Archean sedimentary rocks are not anomalous or only slightly anomalous with respect to Eu anomaly $\left(\mathrm{Eu} / \mathrm{Eu}^{*}=1\right)$ but post-Archean sedimentary rocks on average show a significant 
and constant depletion in $\mathrm{Eu}\left(\mathrm{Eu} / \mathrm{Eu}^{*}=0.65\right)$. This break in composition corresponds to the Archean-Proterozoic boundary [2]. It has also been generally observed that contrary to the Archean, post-Archean sedimentary rocks are enriched in LREE, depleted in HREE and having Eu/Eu ${ }^{*}<1$ and $(\mathrm{Gd} / \mathrm{Yb}) \mathrm{n}<2$ [24]. It is because LREE (La-Sm) are more incompatible in typical igneous differentiation processes than the HREE (Gd-Lu). Therefore, there is a general increase in the LREE/HREE ratio from more mafic to more felsic composition. Archean samples generally fall in the range of LREE/HREE $=6-9$ and post-Archean samples typically have values in the range of LREE/HREE $=8-12$ [2]. Hence the REE patterns and the ratios like LREE/HREE, (La/Yb)n, $(\mathrm{Gd} / \mathrm{Yb}) \mathrm{n}$ and $\mathrm{Eu} / \mathrm{Eu}^{*}$ gives a broad hint of felsic source rocks.

All the sandstone and quartzite samples show $\mathrm{Eu} / \mathrm{Eu}^{\star}$ in a narrow range with an average of 0.63 for sandstones and 0.49 for quartzites and are identical to that of the UCC (0.65) and granite of the Bastar craton (0.65) (Table 2). Eu is not fractionated during weathering or digenesis relative to other REE [1]. Therefore increasing size of Eu anomaly in these samples reflects input from source rocks with an increasingly large negative Eu anomaly. There is no systematic difference in REE patterns among the formations of the sandstones and quartzites, probably due to presence of common heavy minerals like zircon and garnet derived from common felsic source [2]. The average $(\mathrm{Gd} / \mathrm{Yb}) \mathrm{n}$ of sandstones is 1.3 and that of quartzites is 1.2 and this ratio is close to UCC. Therefore, we assume that these sandstones and quartzites were derived from source rocks similar to UCC. Average $\Sigma$ HREE ( 3.56) of sandstone and average $\Sigma$ HREE ( 3.56) of sandstone shows a strong depletion of $\Sigma$ HREE relative to quartzites and UCC, it is due to lesser concentration of heavy minerals especially zircon and garnet which have a high concentration of $\Sigma$ HREE. Low amounts of heavy minerals in sandstones compared to quartzites are consistent with petrography. The sandstone samples have average $(\mathrm{Gd} / \mathrm{Yb}) \mathrm{n}$ ratio of 1.3 and quartzites have average $(\mathrm{Gd} / \mathrm{Yb}) \mathrm{n}$ ratio of 1.2 suggesting that these sediments were derived from sources having somewhat depleted $\Sigma$ HREE felsic rocks like granites and gneisses rather than mafic rocks.

These REE data of sandstones and quartzites have been compared with available REE data of the Archean Basement rocks like granites, gneisses and mafic volcanic rocks of the Bastar craton [25] [26] to delineate the end member compositions (Figure 4). The general shapes of REE patterns for sandstones and quartzites are similar to the granite and gneiss of the Bastar craton and do not match with the REE patterns of mafic volcanic rocks (Figure 4). This suggests that sandstones and quartzites could have been derived by the contributions from nearby gneisses and granites of the Bastar craton and contribution from mafic volcanic might be insignificant. However, there may be some contribution of sediments from mafic volcanics also, but the REE budget in clastic sedimentary rocks is chiefly controlled by granitoids, which mask the contribution of mafic-ultramafic components [27]. Further, (La/Yb)n, (Gd/Yb)n and Eu/Eu* ratios of granite and gneiss of the Bastar craton overlap with the respective ratios 


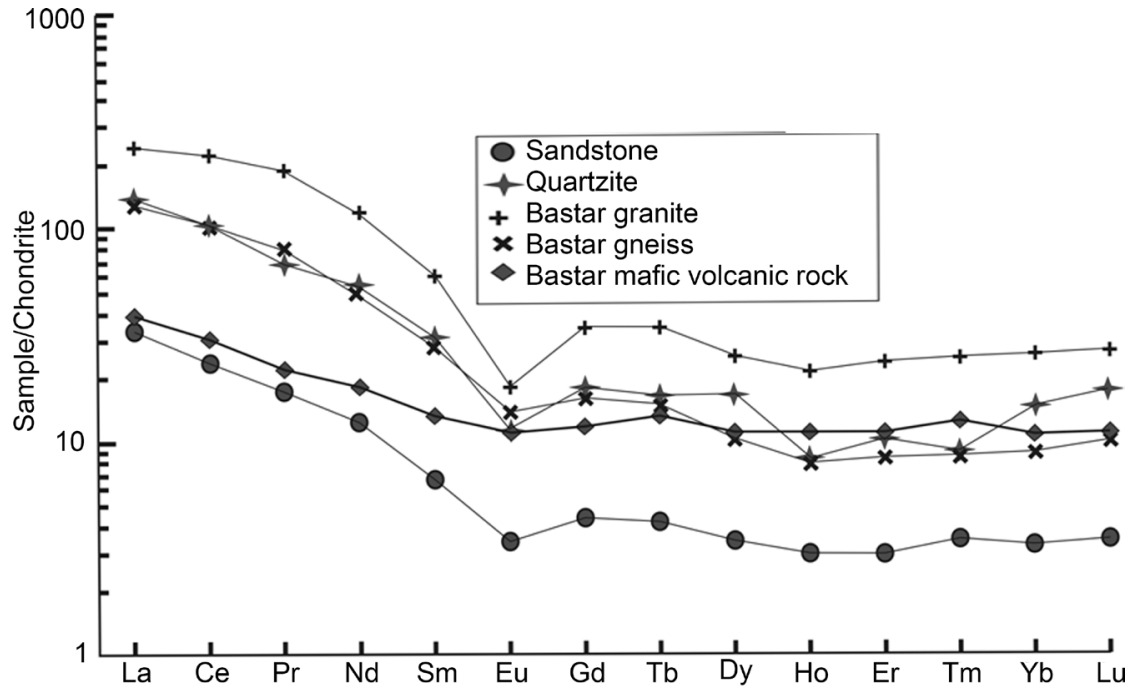

Figure 4. Chondrite normalized average REE patterns of the Paleoproterozoic quartzites and the Meso-Neoproterozoic sandstones of the Bastar craton. Chondrite normalized REE patterns of the granite, gneiss and mafic volcanic rocks of the Bastar craton have been shown for comparison. Data of the granite and gneiss of the Bastar craton have been taken from [25], mafic volcanic rocks from [26] and Chondrite normalization values from [21].

of sandstone and quartzites samples again suggesting that granite and gneiss could have been the source rocks for these sandstones. It is here necessary to mention that that the Paleoproterozoic Sakoli and Saucer sediments have undergone greenschist to lower amphibolite facies of metamorphism. According to McLennan [1] (1989) REE are mobile in some circumstances and these circumstances has rarely been debated. The REE patterns of the quartzites and their ratios like $(\mathrm{La} / \mathrm{Yb}) \mathrm{n},(\mathrm{Gd} / \mathrm{Yb}) \mathrm{n}$ and $\mathrm{Eu} / \mathrm{Eu}^{*}$ are similar to sandstones and Archean granite and gneiss of the Bastar craton. It indicates that the REE in quartzites have not been mobilized during metamorphism and therefore directly mimic the REE patterns of the protolith.

Therefore with the identification of several likely source components it is possible to quantitatively model the relative contribution of granite, gneiss and mafic rock end members in the source terrain of the exposed upper crust which contributed detritus to the sandstones of the Chhattisgarh and Indravati basins and, the quartzites of the Sakoli and Saucer basins of the Bastar craton. The REE data of basement granite and gneiss [25] mafic volcanic rocks [26] occurring in the Bastar craton are taken as end members for modelling purpose. To determine the contribution of these components of basement rocks to the overall composition of sandstones and quartzites, the mixing calculations are performed. Parameters and results of mixing calculations are shown in Table 3 and Figure 5. REE modeling reveals that average sandstone represent mixture of sediments derived from a provenance consisting of $20 \%$ granite (G), $70 \%$ gneiss $(\mathrm{Gn})$ and $10 \%$ mafic rocks $(\mathrm{M})$. The total individual REE abundances and ratios like $(\mathrm{La} / \mathrm{Sm}) \mathrm{n},(\mathrm{La} / \mathrm{Yb}) \mathrm{n}$ and $(\mathrm{Gd} / \mathrm{Yb}) \mathrm{n}$ are in excellent agreement with model values. Interestingly, the average quartzite also shows best agreement with the 
model of mixture of sediments derived from a provenance consisting of $20 \%$ granite $(\mathrm{G}), 70 \%$ gneiss $(\mathrm{Gn})$ and $10 \%$ mafic rocks $(\mathrm{M})$. The ratios like $(\mathrm{La} / \mathrm{Yb}) \mathrm{n}$ and $(\mathrm{Gd} / \mathrm{Yb}) \mathrm{n}$ are also in excellent agreement with model values.

The significant outcome of the modeling is that the exposed the Proterozoic upper crust of the Bastar craton during the sedimentation of the Paleoproterozoic Sakoli and saucer and the Meso-Neoproterozoic Chhattisgarh and Indravati basins of the Bastar craton was largely consisted of gneissic rocks (70\%), with an little contribution (20\%) from Late Archean (2.5 Ga) granites. The composition of Paleoproterozoic upper crust of Bastar craton seems to be similar to that $\mathrm{Me}$ so-Neoproterozoic upper continental crust. The compositional similarity can be adequately attributed to the continuous unroofing of gneissic and granitic rocks with minor contribution from mafic volcanic rocks.

\subsection{Proterozoic Crustal Composition}

The mixing REE modeling and other REE characteristics show dominant mixing of two end member felsic source compositions (gneiss $70 \%+$ granite $20 \%$ ) and

Table 3. Results of mixing calculations.

\begin{tabular}{|c|c|c|c|c|c|c|c|c|c|c|c|c|}
\hline \multirow[b]{3}{*}{ Elements } & \multicolumn{2}{|c|}{ Average } & \multicolumn{2}{|c|}{ Average } & \multicolumn{2}{|c|}{ Average } & \multicolumn{2}{|c|}{ Average } & \multicolumn{2}{|c|}{ Average } & \multicolumn{2}{|c|}{ Mixing results } \\
\hline & \multicolumn{2}{|c|}{ sandstone (S) } & \multicolumn{2}{|c|}{ Quartzite (Q) } & \multicolumn{2}{|c|}{ Granite (G) } & \multicolumn{2}{|c|}{ gneiss (Gn) } & \multicolumn{2}{|c|}{ volcanics (V) } & \multicolumn{2}{|c|}{ G20:Gn70:V10 } \\
\hline & ppm & $\mathrm{N}$ & ppm & $\mathrm{N}$ & ppm & $\mathrm{N}$ & ppm & $\mathrm{N}$ & ppm & $\mathrm{N}$ & ppm & $\mathrm{N}$ \\
\hline $\mathrm{La}$ & 7.8 & 33 & 32 & 135.9 & 57 & 239.9 & 29.7 & 125.3 & 9.2 & 38.9 & 33.07 & 139.6 \\
\hline $\mathrm{Ce}$ & 14.6 & 23.8 & 62 & 101.8 & 134 & 218.4 & 61.2 & 99.9 & 18.5 & 30.2 & 71.47 & 116.6 \\
\hline $\operatorname{Pr}$ & 1.6 & 17.3 & 6.5 & 69.8 & 18 & 191.5 & 7.4 & 79.7 & 2 & 22.1 & 8.92 & 96.3 \\
\hline $\mathrm{Nd}$ & 5.8 & 12.7 & 25 & 54.5 & 56 & 122.4 & 22.5 & 49.2 & 8.5 & 18.5 & 27.78 & 60.8 \\
\hline $\mathrm{Sm}$ & 1 & 6.9 & 4.7 & 31.7 & 9.2 & 62.3 & 4.2 & 28.9 & 2 & 13.7 & 4.98 & 34 \\
\hline Gd & 0.91 & 4.5 & 3.7 & 18.7 & 7 & 35.5 & 3.3 & 16.633 & 2.4 & 12.2 & 3.95 & 19.9 \\
\hline $\mathrm{Tb}$ & 0.16 & 4.3 & 0.6 & 16.8 & 1.2 & 35.4 & 0.56 & 15.512 & 0.5 & 13.8 & 0.682 & 19.3 \\
\hline Dy & 0.87 & 3.5 & 4.1 & 17 & 6.4 & 26.2 & 2.6 & 10.65 & 2.7 & 11.3 & 3.37 & 13.8 \\
\hline Ho & 0.17 & 3 & 0.5 & 8.7 & 1.2 & 21.9 & 0.45 & 8.2418 & 0.62 & 11.3 & 0.617 & 11.3 \\
\hline Er & 0.5 & 3.1 & 1.6 & 10.5 & 3.9 & 24.6 & 1.4 & 8.75 & 1.8 & 11.4 & 1.94 & 12.1 \\
\hline $\mathrm{Tm}$ & 0.09 & 3.6 & 0.2 & 9.1 & 0.6 & 25.5 & 0.22 & 8.9069 & 0.32 & 12.9 & 0.312 & 12.6 \\
\hline $\mathrm{Yb}$ & 0.57 & 3.5 & 2.4 & 15.1 & 4.3 & 26.8 & 1.5 & 9.5031 & 1.8 & 11.3 & 2.09 & 13.1 \\
\hline $\mathrm{Lu}$ & 0.09 & 3.4 & 0.4 & 16.9 & 0.7 & 27.6 & 0.26 & 10.569 & 0.28 & 11.3 & 0.346 & 14 \\
\hline$(\mathrm{Gd} / \mathrm{Yb}) \mathrm{n}$ & & 1.3 & & 1.2 & & 1.34 & & 1.82 & & 1.1 & & 1.6 \\
\hline $\mathrm{Eu} / \mathrm{Eu}^{\star}$ & & 0.63 & & 0.49 & & 0.39 & & 0.64 & & 0.89 & & 0.62 \\
\hline
\end{tabular}



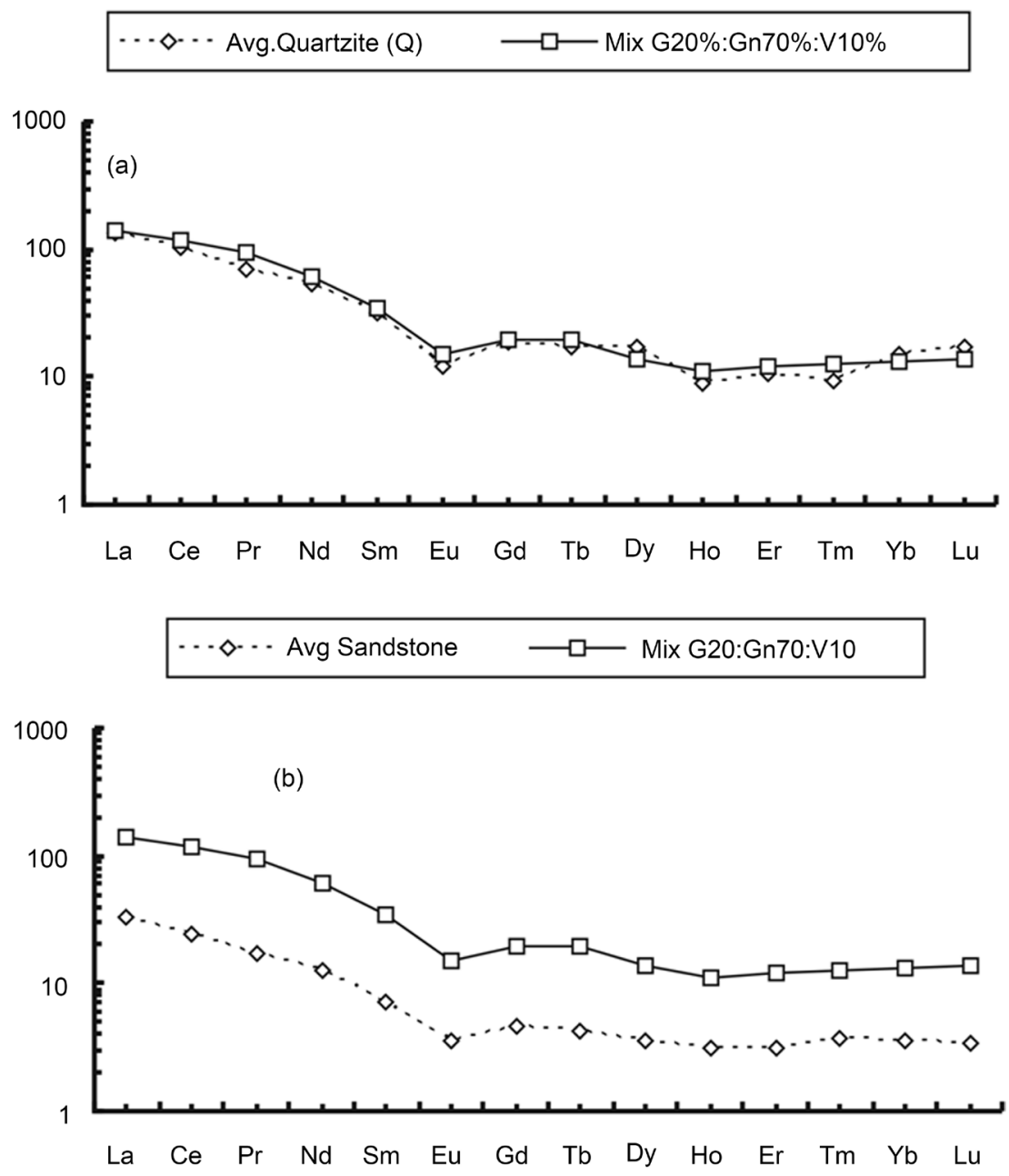

Figure 5. Results of REE modeling for estimating source rock contribution (a) REE patterns of average quartzite and estimated provenance after mixing the end members in the proportion of $20 \mathrm{G}: 70 \mathrm{Gn}: 10 \mathrm{M}$. (b) REE patterns of average sandstone and estimated provenance after mixing the end members in the proportion of $20 \mathrm{G}: 70 \mathrm{Gn}: 10 \mathrm{M}$. The REE patterns of average quartzite and sandstone are in excellent agreement with the mixing results.

one end member of mafic composition of insignificant contribution (basalt $10 \%)$. This suggests that the geochemical transition from mafic rich crust to felsic rich crust have occurred completely at Archean-Proterozoic boundary as seen in other cratons of the world [2] reflecting major development of continental crust during Archean not in the Proterozoic in the Bastar craton. When the REE characteristics of Meso-Neoproterozoic Chattisgarh and Indravati basins of the Bastar craton are compared with other Proterozoic basins of Indian Peninsula like the Vindhyan, Cuddapah and Kaladgi basins, these Proterozoic basins of Indian Peninsula also show dominant contribution from felsic source rocks [28] [29] [30] similar to the Proterozoic basins of the Bastar craton. This similarity among these Proterozoic basins of Indian Peninsula indicates that these basins were developed on the upper crust of felsic composition dominated by the Archean gneiss and granite. 


\section{Conclusions}

The REE data indicates source rocks for the Meso-Neoproterozoic sandstones, and the Paleoproterozoic quartzites were felsic in nature and the source rocks are identified to be granite and gneiss of the Bastar craton. The data also show similarities in REE patterns and ratios like $\left.\mathrm{Eu} / \mathrm{Eu}^{*},(\mathrm{La} / \mathrm{Lu}) \mathrm{n}, \mathrm{La} / \mathrm{Gd}\right) \mathrm{n}$ ratios between the Meso-Neoproterozoic sandstones of the Chandarpur Group of the Chhattisgarh basin and the Tiratgarh Formation of the Indravati basin. The sandstones of the Chhattisgarh basin and the Indravati basin also show REE similarities, thus indicate homogeneity in the source rock composition during the Meso-Neoproterozoic time and also indicate that the sediments for the MesoNeoproterozoic Chhattisgarh and Indravati basins have been derived from similar sources i.e. granite and gneiss of the Bastar craton. REE modeling reveals that average sandstone and quartzite represent mixture of sediments derived from a provenance consisting of $20 \%$ granite $(\mathrm{G}), 70 \%$ gneiss and $10 \%$ mafic rocks (M).

The granites of the Bastar craton were emplaced at $2.6 \mathrm{Ga}$ [17]. The interval between the granite emplacement in the Archean and their equal contribution in both the Paleoproterozoic and Meso-Neoproterozoic indicates continuous exposure of granites during the Proterozoic. The overall REE characteristics of the sandstones and quartzites of the Bastar craton suggest that the composition of the source region of the Proterozoic rocks represented an evolved stage of dominant felsic crustal composition (gneiss + granite) of the Proterozoic continental crust in the Bastar craton. These features suggest the emergence of fully evolved upper continental crust on the Bastar craton during the Proterozoic.

\section{Acknowledgements}

I wish to express sincere thanks to Dr. V. Balaram, Head Geochemistry Division, NGRI, Hyderabad for providing lab facilities during chemical analysis. H.W. thanks the Principal, Govt. Amar Singh College, Srinagar for encouragement and help during this work and thankfully acknowledges the Fellowship of CSIR, Govt. of India.

\section{References}

[1] McLennan, S.M. (1989) Rare Earth Elements in Sedimentary Rocks: Influence of Provenance and Sedimentary Process. Review of Mineralogy, 21, 169-200.

[2] Taylor, S.R. and McLennan, S.M. (1985) The Continental Crust: Its Composition and Evolution. Blackwell, Oxford.

[3] Bhatia, M.R. and Crook, K.A.W. (1986) Trace Element Characteristics of Greywackes and Tectonic Discrimination of Sedimentary Basins. Contribution to Mineralogy and Petrology, 92, 181-193. https://doi.org/10.1007/BF00375292

[4] Condie, K.C. (1993) Chemical Composition and Evolution of the Upper Continental Crust; Contrasting Results from Surface Samples and Shales. Chemical Geology, 104, 1-37. https://doi.org/10.1016/0009-2541(93)90140-E

[5] Haskin, L.A., Wildeman, T.R., Frey, F.A., Collins, K.A., Keedy, C.R. and Haskin, M.A. (1966) Rare Earths in Sediments. Journal of Geophysical Research, 71, 60916105. https://doi.org/10.1029/JZ071i024p06091 
[6] Nance, W.B. and Taylor, S.R. (1977) Rare Earth Element Pattern and Crustal Evolution-II. Archean Sedimentary Rocks from Kalgoorlie, Australia. Geochimica et Cosmochimica Acta, 41, 225-231. https://doi.org/10.1016/0016-7037(77)90229-0

[7] Chaudhri, S. and Cullers, R.L. (1979) The Distribution of Rare-Earth Elements in Deeply Buried Gulf Coast Sediments. Chemical Geology, 24, 327-338. https://doi.org/10.1016/0009-2541(79)90131-1

[8] Rogers, J.J.W. (1986) The Dharwar Craton and the Assembly of Peninsular India. Journal of Geology, 94, 129-143. https://doi.org/10.1086/629019

[9] Radhakrishna, B.P and Naqvi, S.M. (1986) Precambrian Continental Crust of India and Its Evolution. The Journal of Geology, 94, 145-166.

https://doi.org/10.1086/629020

[10] Ramakrishnan, M. (1990) Crustal Development in Southern Bastar, Central Indian Craton, Southern. Geological Survey of India Special Publication, 28, 44-66.

[11] Naqvi, S.M. and Rogers, J.J.W. (1987) Precambrian Geology of India. Oxford University Press, New York, 223.

[12] Shastry, B.V. and Dekate, Y.G. (1984) Petrochemistry of the Sakoli and Saucer Metasediments in Southern Part of Balaghat District, Madhya Pradesh. Geological Survey of India, Special Publication, 12, 485-490.

[13] Murthi, K.S. (1987) Stratigraphy and Sedimentation in Chhattisgarh Basin. Geological Society of India, Memoir, 6, 239-260.

[14] Bandyopadhaya, B.K., Roy, A. and Huin, A.K. (1995) Structure and Tectonics of a Part of the Central Indian Shield. Geological Society of India, Memoir, 31, 433-468.

[15] Bhowmik, S.K., Pal, T., Roy A. and Chatterjee, K.K. (1997) Penecontemporaneous Deformation Structures in Relation to Diagenesis of Carbonate-Hosted Manganese Ores: An Example from Polydeformed and Metamorphosed Sausar Belt. Indian Minerals, 51, 149-164.

[16] Ghosh, P.K., Chandy, K.C., Bishui, P.K. and Prasad, R. (1986) Rb-Sr Age of Granitic Gneiss in Malanjkhand Area, Balaghat District, Madhya Pradesh. Indian Minerals, 40, 1-8.

[17] Sarkar, A., Sarkar, G., Paul, D.K. and Mitra, N.D. (1990) Precambrian Geochronology of the Central Indian Shield-A Review. Geological Society of India Special Publication, 28, 453-482.

[18] Sarkar, G., Paul, D.K., deLaeter, J.R., McNaughton, N.J. and Mishra, V.P. (1990b) A Geochemical and $\mathrm{Pb}, \mathrm{Sr}$ Isotopic Study of the Evolution of Granite Gneisses from the Bastar Craton, Central India. Journal of Geological Society of India, 35, 480-496.

[19] Patranabis Deb, S., Bickford, M.E., Hill, B., Chaudhuri, A.K. and Basu, A. (2007) SHRIMP Ages of Zircon in the Uppermost Tuff in Chattisgarh Basin in the Central India $~ 500-\mathrm{Ma}$ Adjustment in Indian Proterozoic Stratigraphy. The Journal of Geology, 115, 407-415. https://doi.org/10.1086/518049

[20] Roy, P., Balaram, V., Kumar, A., Satyanarayanan, M. and Rao, G. (2007) New REE and Trace Element Data on Two International Kimberlitic Reference Materials by ICP-MS. Journal of Geostandards and Geoanalytical Research, 31, 261-273. https://doi.org/10.1111/j.1751-908X.2007.00836.X

[21] Sun, S.S. and McDonough, W.F. (1989) Chemical and Isotopic Systematics of Oceanic Basalts: Implications for Mantle Composition and Processes. Geological Society of London Special Publication, 42, 313-345. https://doi.org/10.1144/GSL.SP.1989.042.01.19

[22] Cullers, R.L. (1988) Mineralogical and Chemical Changes of Soil and Stream Sediment Formed by Intense Weathering of the Danberg Granite, Georgia, USA. Lithos, 


\section{1, 301-314. https://doi.org/10.1016/0024-4937(88)90035-7}

[23] Cullers, R.L., Barrent, T., Carlson, R. and Robinson, B. (1987) Rare Earth Element and Mineralogical Changes in Holocene Soil and Stream Sediment: A Case Study in the Wet Mountains, Colorado, USA. Chemical Geology, 63, 275-297.

https://doi.org/10.1016/0009-2541(87)90167-7

[24] McLennan, S.M., Hemming, S., McDaniel, D.K. and Hanson, G.N. (1993) Geochemical Approaches to Sedimentation, Provenance and Tectonics. Geological Society of America, Special Publication, 284, 21-40. https://doi.org/10.1130/SPE284-p21

[25] Mondal, M.E.A., Hussain, M.F. and Ahmad, T. (2006) Continental Growth of Bastar Craton, Central Indian Shield during Precambrian via Multiphase Subduction and Lithospheric Extension/Rifting: Evidence from Geochemistry of Gneisses, Granitoids and Mafic Dykes. Journal of Geosciences Japan, 49, 137-151.

[26] Sirivastava, R.K., Singh, R.K. and Verma, S.P. (2004) Neoarchean Mafic Volcanic Rocks from the Southern Bastar Greenstone Belt, Central India: Petrological and Tectonic Significance. Precambrian Research, 131, 305-322.

https://doi.org/10.1016/j.precamres.2003.12.013

[27] Jahn, B.M. and Condie, K.C. (1995) Evolution of the Kaapvaal Craton as Viewed from Geochemical and Sm-Nd Isotopic Analyses of Intracratonic Pelites. Geochimica Cosmochimica Acta, 59, 2239-2258. https://doi.org/10.1016/0016-7037(95)00103-7

[28] Rao, V.V.S., Sreenivas, B., Balram, V., Govil, P.K. and Srinivasan, R. (1999) The Nature of the Archean Upper Crust as Revealed by the Geochemistry of the Proterozoic Shales of the Kaladgi Basin, Karnataka Southern India. Precambrian Research, 98, 53-65. https://doi.org/10.1016/S0301-9268(99)00038-8

[29] Paikaray, S., Banerjee, S. and Mukherji, S. (2007) Geochemistry of Shales from the Paleoproterozoic to Neoproterozoic Vindhyan Supergroup: Implications on Provenance, Tectonics and Paleoweathering. Journal of Asian Earth Sciences, 32, 34-38. https://doi.org/10.1016/j.jseaes.2007.10.002

[30] Manikyamba, C., Kerrich, R., Alvarez, I.G., Mathur, R. and Khanna, T.C. (2008) Geochemistry of Paleoproterozoic Black Shales from Intracontimental Cuddapah Basin, India: Implications for Provenance, Tectonic Setting and Weathering Intensity. Precambrian Research, 162, 424-440. https://doi.org/10.1016/j.precamres.2007.10.003 
Submit or recommend next manuscript to SCIRP and we will provide best service for you:

Accepting pre-submission inquiries through Email, Facebook, LinkedIn, Twitter, etc. A wide selection of journals (inclusive of 9 subjects, more than 200 journals)

Providing 24-hour high-quality service

User-friendly online submission system

Fair and swift peer-review system

Efficient typesetting and proofreading procedure

Display of the result of downloads and visits, as well as the number of cited articles Maximum dissemination of your research work

Submit your manuscript at: http://papersubmission.scirp.org/

Or contact ijg@scirp.org 